\title{
SPATIAL DISTRIBUTION OF WATER EROSION RISK IN A WATERSHED WITH EUCALYPTUS AND ATLANTIC FOREST
}

\author{
Distribuição espacial do risco de erosão hídrica em uma bacia hidrográfica \\ com eucalipto e Mata Atlântica
}

\author{
Junior Cesar Avanzi ${ }^{1}$, Marx Leandro Naves Silva², Nilton Curi², \\ Lloyd Darrell Norton ${ }^{3}$, Samuel Beskow ${ }^{4}$, Sérgio Gualberto Martins ${ }^{5}$
}

\begin{abstract}
The process of water erosion occurs in watersheds throughout the world and it is strongly affected by anthropogenic influences. Thus, the knowledge of these processes is extremely necessary for planning of conservation efforts. This study was performed in an experimental forested watershed in order to predict the average potential annual soil loss by water erosion using the Universal Soil Loss Equation (USLE) and a Geographic Information System (GIS), and then compared with soil loss tolerance. All the USLE factors were generated in a distributed approach employing a GIS tool. The layers were multiplied in the GIS framework in order to predict soil erosion rates. Results showed that the average soil loss was $6.2 \mathrm{Mg} \mathrm{ha}^{-1} \mathrm{yr}^{-1}$. Relative to soil loss tolerance, $83 \%$ of the area had an erosion rate lesser than the tolerable value. According to soil loss classes, $49 \%$ of the watershed had erosion less than $2.5 \mathrm{Mg} \mathrm{ha}^{-1} \mathrm{yr}^{-1}$. However, about $8.7 \%$ of the watershed had erosion rates greater than $15 \mathrm{Mg} \mathrm{ha}^{-1} \mathrm{yr}^{-1}$, being mainly related to Plinthosol soil class and roads, thus requiring special attention for the improvement of sustainable management practices for such areas. Eucalyptus cultivation was found to have soil loss greater than Atlantic Forest. Thus, an effort should be made to bring the erosion rates closer to the native forest. Implementation of the USLE model in a GIS framework was found to be a simple and useful tool for predicting the spatial variation of soil erosion risk and identifying critical areas for conservation efforts.
\end{abstract}

Index terms: Forest systems, soil losses, USLE, GIS, coastal plain.

\section{RESUMO}

O processo de erosão hídrica ocorre em todo mundo sendo fortemente afetado por influências antrópicas. Assim, o conhecimento desses processos é extremamente necessário para o planejamento de práticas de conservação do solo. $\mathrm{O}$ estudo foi conduzido em uma bacia hidrográfica experimental florestada com o objetivo de estimar o potencial médio de perdas de solo anuais por erosão hídrica, utilizando a Equação Universal de Perdas de Solo (EUPS) inserida no Sistema de Informação Geográfica (SIG), e comparar com a tolerância de perdas de solo. Todos os fatores da EUPS foram gerados de forma distribuída utilizando a plataforma SIG. Os mapas foram multiplicados no ambiente SIG para estimar as taxas de erosão do solo. Os resultados mostraram que a perda de solo média foi de $6,2 \mathrm{Mg}$ $\mathrm{ha}^{-1}$ ano $^{-1}$. Em relação à tolerância de perdas de solo, $83 \%$ apresentaram taxas de erosão menores que o valor de tolerância permitido. Com relação às classes de perdas de solo, $49 \%$ da bacia tiveram perdas de solo menores que $2,5 \mathrm{Mg} \mathrm{ha}^{-1}$ ano ${ }^{-1}$. Entretanto, cerca de $8,7 \%$ da área da bacia apontaram taxas de erosão maiores que $15 \mathrm{Mg} \mathrm{ha}^{-1}$ ano $^{-1}$, estando, principalmente, relacionada à classe de solo Plintossolo e as estradas, exigindo uma atenção especial para conduzir um manejo sustentável nessas áreas. O cultivo de eucalipto mostrou perdas de solo maiores que a Mata Atlântica. Desse modo, um esforço deve ser realizado a fim de aproximar as taxas de erosão para próximo dos valores na mata nativa. A implementação do modelo EUPS no ambiente SIG mostrou ser uma ferramenta simples e útil para predição da variação espacial do risco de erosão do solo e na identificação das áreas críticas para focar os esforços de conservação.

Termo para indexação: Sistemas florestais, perdas de solo, EUPS, SIG, tabuleiros costeiros.

(Received in july 24, 2013 and approved in september 18, 2013)

\section{INTRODUCTION}

The process of water erosion occurs in watersheds throughout the world and it is strongly affected by anthropogenic influences. Modification of natural ecosystems can cause intense environmental degradation, onsite and offsite. Erosion in advanced stages can not only transport sediments but also remove nutrients, organic carbon and agrochemical contaminants to outside the systems, resulting in a decrease of overall land productivity. Knowledge about soil erosion processes and the speed in which soil is eroded is necessary for planning of

\footnotetext{
${ }^{1}$ Empresa Brasileira de Pesquisa Agropecuária/Embrapa - Centro Nacional de Pesquisa em Pesca, Aquicultura e Sistemas Agrícolas - Quadra 104 Sul Avenida LO 1 - n. 34 - 1 e 2 pavimentos - Plano Diretor Sul - 77020-020 - Palmas - TO - Brasil - junior.avanzi@embrapa.br

${ }^{2}$ Universidade Federal de Lavras/UFLA - Departamento de Ciência do Solo/DCS - Lavras - MG - Brasil

${ }^{3}$ USDA-ARS National Soil Erosion Research Laboratory/NSERL - West Lafayette - IN - USA

${ }^{4}$ Universidade Federal de Pelotas/UFPel - Centro de Desenvolvimento Tecnológico/Engenharia Hídrica - Pelotas - RS -Brasil

5Universidade Federal de São João del-Rey/UFSJ - São João del-Rey - MG - Brasil
} 
conservation efforts. Modeling is a tool to provide a quantitative and consistent approach to predict soil loss and the sediment delivery ratio under a wide range of conditions (BHATTARAI; DUTTA, 2007). In addition, it can be used to evaluate hypotheses and determine the appropriate soil management and land use for each site (TUCCI, 1998).

Simple empirical methods, such as the Universal Soil Loss Equation (USLE) (WISCHMEIER; SMITH, 1978), have been used for the assessment of soil erosion at the watershed scale (BHATTARAI; DUTTA, 2007; PANDEY; CHOWDARY; MAL, 2007; DABRAL; BAITHURI; PANDY, 2008; BESKOW et al., 2009). The USLE is the simplest and most widely used model for erosion prediction, which estimates the long-term annual average rate of erosion with generally acceptable accuracy. Basically, the USLE estimates the soil loss per unit area based on the following factors (WISCHMEIER; SMITH, 1978): rainfall erosivity (R), soil erodibility (K), topography (LS), covermanagement $(C)$, and support practices $(\mathrm{P})$.

The combination of USLE and a Geographic Information System (GIS) has been found to be an effective and suitable approach for estimating the magnitude and spatial distribution of erosion. USLE model applications in a GIS framework allow analyzing rapidly soil erosion by means of an in-depth analysis since this process can account for spatial variability (PANDEY et al., 2007). Soil erosion estimates using GIS techniques enable planners to identify sites which are susceptible to water erosion and also provides a quantitative measure of soil loss at different scales (MARTIN; SAHA, 2007).

The main reason for using a GIS is that the erosion process varies spatially, so that cell sizes should be used allowing spatial variation to be taken into account (DE ROO; JETTEN, 1999). The same researchers also reported that the amount of data necessary for a great amount of cells is required for an accurate representation of the watershed. Since it is not practicable to input data manually, GIS can be used to gather and access databases.

The objective of this study was to evaluate soil loss risk caused by water erosion in a watershed located at the Coastal Plain region of Brazil applying the USLE model coupled with a GIS framework, and then the soil loss will be compared with the soil loss tolerance. It is expected that this methodology will provide a useful tool to identify high risk areas for soil erosion, thus allowing the proposal of adequate conservation and management practices in the studied watershed and in similar ones of the Brazilian Coastal Plain region, which occupy around 100 million hectares.

\section{MATERIAL AND METHODS}

\section{Study Area and Soil Description}

The experimental watershed is located in the Fibria Celulose S.A. area, Aracruz County, Espírito Santo state, southeastern Brazil, between parallels $19^{\circ} 51^{\prime} \mathrm{S}$ and $19^{\circ} 53^{\prime}$ S and, between meridians $40^{\circ} 11^{\prime} \mathrm{W}$ and $40^{\circ} 14^{\prime} \mathrm{W}$ (Figure 1). According to Köppen classification, the climate of this region is Aw (tropical with rainy summer and dry winter), with average annual rainfall equal to $1,400 \mathrm{~mm}$ (EMBRAPA, 2000). The watershed has a drainage area of 286 ha, containing eucalyptus plantations and Atlantic Forest, with advanced regeneration.

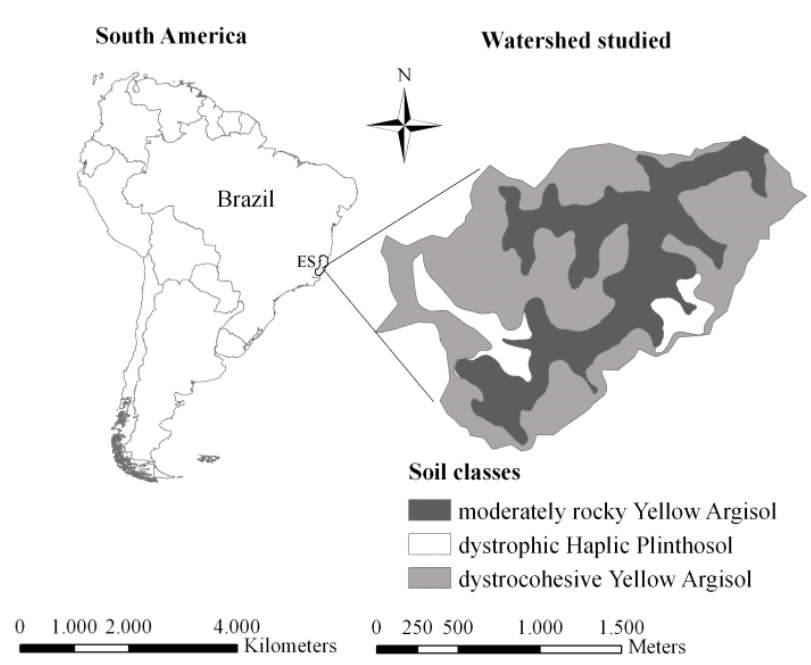

Figure 1 - Location of the study area and soil map for the experimental watershed.

The soil classification in the watershed was performed in accordance with classification recommended by Embrapa (2006). The watershed includes the following soil classes, which are the most representative soils of the Brazilian Coastal Plain, since they represent 100 millions of hectares of Brazilian Coast: a) dystrocohesive Yellow Argisol - PA1, b) moderately rocky Yellow Argisol - PA2, and c) dystrophic Haplic Plinthosol - FX.

\section{Universal Soil Loss Equation (USLE)}

The USLE allows an estimate of the long-term annual average soil loss under specific conditions. This model was applied in a GIS environment to evaluate the potential soil loss and its distribution in a forested watershed at the Brazilian Coastal Plain. The USLE computes soil loss as the product of six factors (Equation 1) (WISCHMEIER; SMITH, 1978): 


$$
\mathrm{A}=\mathrm{R} \times \mathrm{K} \times \mathrm{L} \times \mathrm{S} \times \mathrm{C} \times \mathrm{P}
$$

where: $\mathrm{A}$ is the average annual soil loss per unit of area $\left(\mathrm{Mg} \mathrm{ha}^{-1} \mathrm{yr}^{-1}\right), \mathrm{R}$ represents the average annual rainfall erosivity factor ( $\mathrm{MJ} \mathrm{mm} \mathrm{ha-1} \mathrm{h}^{-1} \mathrm{yr}^{-1}$ ), $\mathrm{K}$ is the soil erodibility factor $\left(\mathrm{Mg} \mathrm{h} \mathrm{MJ} \mathrm{Mm}^{-1}\right), \mathrm{L}$ corresponds to the slope length factor (dimensionless), $\mathrm{S}$ is the slope steepness factor (dimensionless), $\mathrm{C}$ represents the cover management factor (dimensionless), and $\mathrm{P}$ is the support practice factor (dimensionless). For the calculation of soil erosion risk, data sets of rainfall and sediments from erosion plots were collected from November 1997 to May 2004.

A Geographic Information System (GIS) was used in order to enable authors to deal with USLE parameters and predictions spatially distributed. The details of all factors in Equation (1), which were represented in a 10-meter-resolution map, are described below. The data were analyzed with the software ArcGIS 9.3 (ESRI, 2009).

a) Rainfall erosivity factor $(\mathrm{R})$

The R factor was calculated by Martins et al. (2010a) (Figure 2). These authors used data set of rainfall recorded every 5 minutes from January 1998 to July 2004.

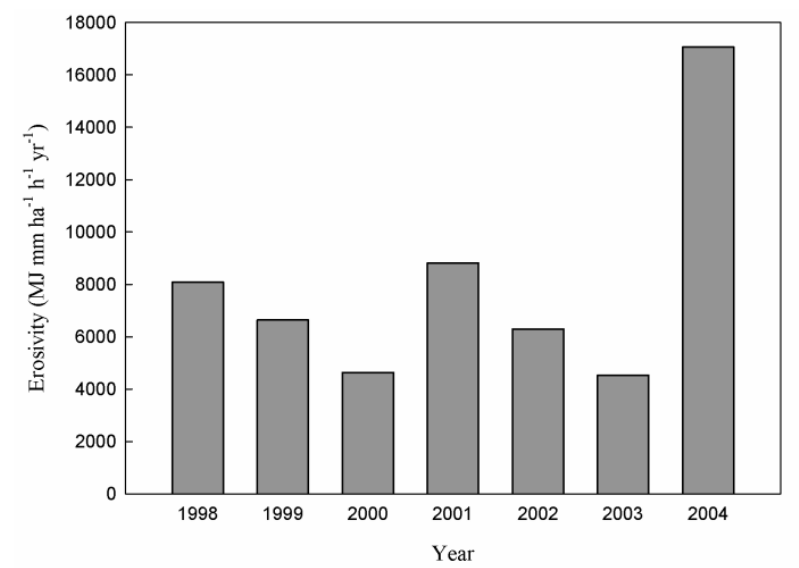

Figure 2 - Rainfall erosivity index for the studied watershed (Adapted from MARTINS et al., 2010a).

b) Soil erodibility factor $(\mathrm{K})$

The $\mathrm{K}$ factor for each soil class in the studied watershed was determined by an earlier study which was carried out by Martins et al. (2011). The K values used were $0.007,0.017$, and $0.0004 \mathrm{Mg} \mathrm{h} \mathrm{MJ}^{-1} \mathrm{~mm}^{-1}$ for PA1, FX, and PA2, respectively. The $\mathrm{K}$ factor map was created with the aid of GIS tools and derived from the soil map of the area.

c) Topographic factor (LS)

In this study, a large number of elevation points were surveyed throughout the watershed, which allowed the generation of a 10-m-resolution Digital Elevation Model (DEM) (Figure 3). In order to characterize soil loss spatially with a good resolution, homogeneous grid cells as small as possible are necessary for feeding the database inputs.

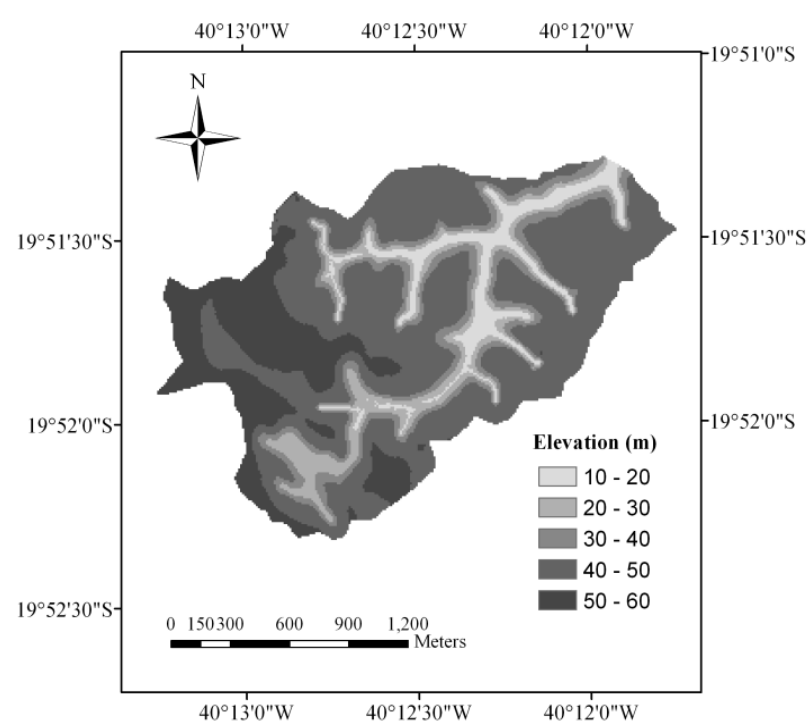

Figure 3 - Digital Elevation Model (DEM) of the experimental watershed.

The DEM was imported to the GIS for developing a slope map; thereafter, the latter map was classified into four classes according to Yuksel, Gundogan and Akay (2008): (i) very gentle to flat ( $<5 \%$ ); (ii) gentle (5-15\%); (iii) steep (15-30\%); and (iv) very steep ( $>30 \%$ ) (Figure 4$)$. The slope length factor (L) and the slope steepness factor (S) were also generated on a grid cell basis.

The slope length factor (L) is expressed by equation 2 (RENARD et al., 1997):

$$
\mathrm{L}=(\lambda / 22.13)^{m}
$$

where: $\lambda$ is the field slope length (m), and $m$ is the slope length exponent (WISCHMEIER; SMITH, 1978). A grid size of $10 \mathrm{~m}$ was used as field slope length $(\lambda)$. Similar procedure was adopted by several researchers 
(BHATTARAI; DUTTA, 2007; PANDEY; CHOWDARY; MAL, 2007; DABRAL; BAITHURI; PANDEY, 2008; BESKOW et al., 2009).

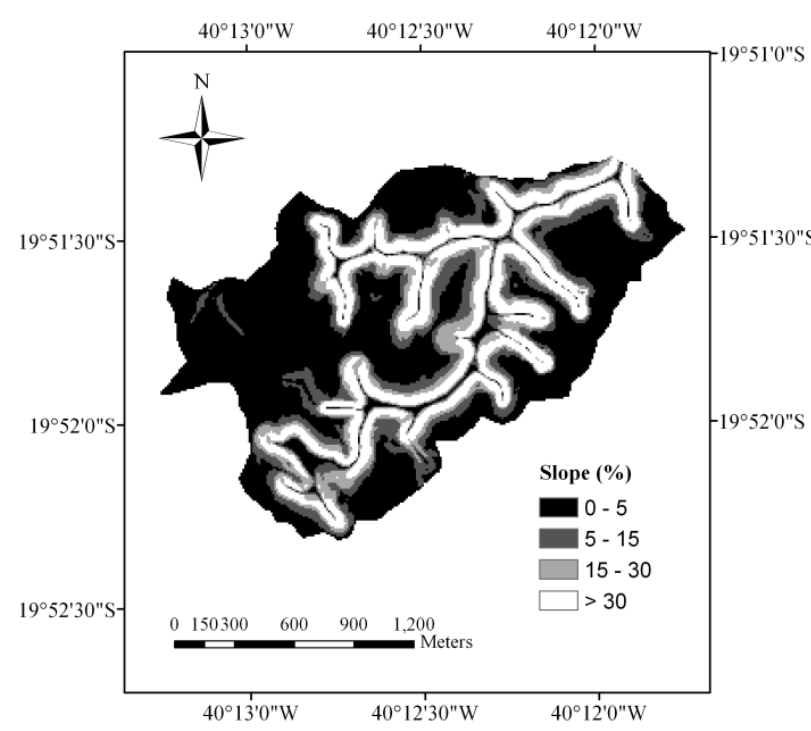

Figure 4 - Map of slope categories for the experimental watershed according to classification recommended by Yuksel, Gundogan and Akay (2008).

The slope-length exponent $m$ is related to the ratio $(\beta)$ of rill to interrill erosion by the following equation 3 (FOSTER; MEYER; ONSTAD, 1977):

$m=\beta /(1+\beta)$

Values for the ratio $\beta$ of rill to interrill erosion were computed according to the equation 4 proposed by McCool et al. (1989):

$\beta=(\sin \theta / 0.0896) /\left[3.0 \cdot(\sin \theta)^{0.8}+0.56\right]$

where: $\theta$ is the slope angle (degree).

The slope-steepness factor (S) was evaluated according to equations 5 and 6 presented in McCool et al. (1987) for slopes greater than $4 \mathrm{~m}$, which were applied in several studies (BHATTARAI; DUTTA, 2007; PANDEY; CHORWDARY; MAL, 2007; DABRAL; BAITHURI; PANDEY, 2008; BESKOW et al., 2009):

$$
\mathrm{S}=10.8 \cdot \sin \theta+0.03 \quad \text { for slope }<9 \%
$$

$$
\mathrm{S}=16.8 \cdot \sin \theta-0.50 \quad \text { for slope } \geq 9 \%
$$

where: $\mathrm{S}$ is the slope steepness factor. The combined LS factor was calculated with the aid of a GIS software by multiplying $\mathrm{L}$ and $\mathrm{S}$ factor maps.

d) Cover management and support practice factors

In this work, the $\mathrm{C}$ factor map was developed based on values published in the research carried out by Martins et al. (2010b) with the same land use. No support practices were considered, so the $\mathrm{P}$ factor was set equal to 1.0 for the entire area. A similar assumption was also adopted by Beskow et al. (2009).

\section{Soil Loss Tolerance (T)}

The $\mathrm{T}$ values, reported by Martins et al. (2010b), were 10,11 and $5 \mathrm{Mg} \mathrm{ha}^{-1} \mathrm{yr}^{-1}$ for the PA1, FX and PA2, respectively. These values were compared to USLE predictions using GIS tools to identify areas where land use and management were appropriate, and to identify areas that need more attention in order to have soil erosion rates reduced and to prevent from long-term soil degradation.

\section{RESULTS AND DISCUSSION}

\section{USLE Parameters}

Annual rainfall erosivity ranged from 4,536 to 17,056 MJ mm ha-1 $\mathrm{h}^{-1} \mathrm{yr}^{-1}$ (Figure 2). This great variation in magnitude indicates that the assessment of the rainfall erosivity for this watershed was indispensable for providing a reliable $\mathrm{R}$ factor estimate. The $\mathrm{R}$ factor calculation based on total rainfall records and/or geographic location can be useful for Brazilian regions where rainfall intensity values have not been recorded. Nevertheless, when this type of information is available, the rainfall erosivity factor should be estimated with such information.

The greatest $\mathrm{R}$ value $\left(17,056 \mathrm{MJ} \mathrm{mm} \mathrm{ha}^{-1} \mathrm{~h}^{-1} \mathrm{yr}^{-1}\right)$ was observed in 2004, however, it is important to note that $\mathrm{R}$ value for March/2004 corresponded to 12,540 MJ $\mathrm{mm} \mathrm{ha} \mathrm{h}^{-1} \mathrm{~h}^{-1}$. It should be mentioned that this monthly value was greater than the annual values for the other six years (Figure 2). This can be justified because a hurricane, the first in modern times, in the South Atlantic Ocean struck the Brazilian coast in this month (LE COMTE, 2005; MCTAGGART-COWAN et al., 2006). Although this hurricane has hit mainly the Santa Catarina state coast, it caused heavy rainfall events with high intensity in a large area of the Brazilian coast, including Espírito Santo state. Because of this unusual extreme event, rainfall erosivity had values greater than any predictions. The spatial 
distribution of R factor in this study was assumed to be constant in the entire watershed which has a drainage area of 286 ha, where a small spatial variability related to both rainfall and rainfall erosivity is expected. This procedure was also adopted by Dabral, Baithuri and Pandey (2008) for a larger watershed with 127,878 hectares in Northeastern India.

The soil erodibility map was generated using results from field plots conducted and measured by Martins et al. (2011). It is worthwhile to point out that the greater the erodibility value, the lesser the resistance of the soil to water erosion. Analyzing the K factor map, it can be noticed that almost all the watershed $(92 \%)$ can be considered as having low soil erodibility, with values less than $0.010 \mathrm{Mg} \mathrm{h} \mathrm{MJ}^{-1} \mathrm{~mm}^{-1}$, while the remaining part has moderate soil erodibility (FOSTER et al., 1981).

The LS factor was calculated by Equations (2), and (5) or (6) taking its spatial variation into account resulting in values from 0.03 to 6.88 (Figure 5). The spatial analysis of the LS factor indicated that $65 \%$ of the watershed had a topographic factor less than 1.0 , thus meaning that in a great part of the watershed, LS factors are not the major responsible for increase the water erosion risk. In addition, it was also found that a considerable area $(52 \%)$ has gradients less than $5 \%$ (Figure 3 ), representing a low risk for soil losses. On the other hand, the steeper slopes may result in more runoff volume and energy, thus originating greater water erosion.

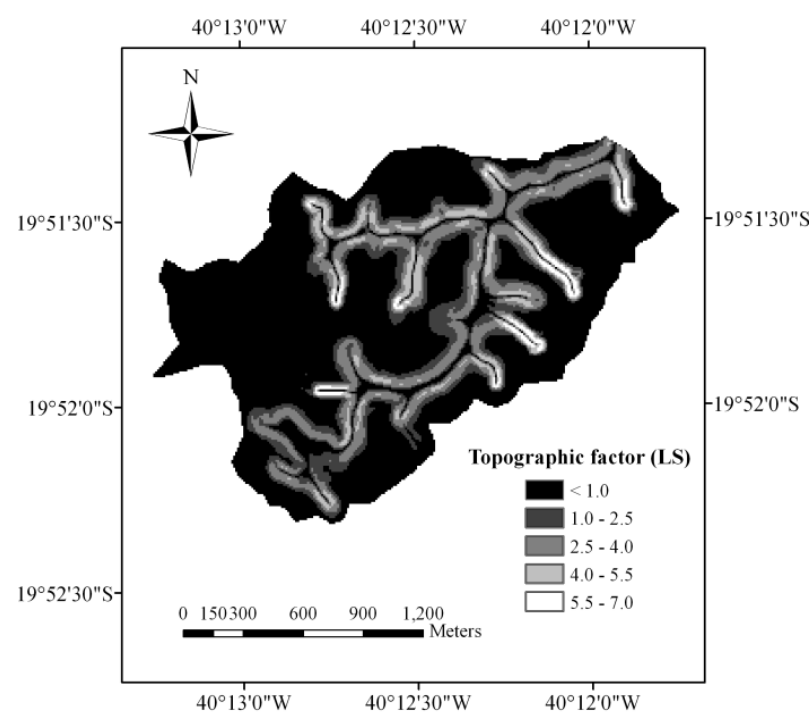

Figure 5 - Topographic factor (LS) map for the studied watershed.
The watershed analyzed in this study is composed of only three types of land use, namely native forest Atlantic Forest (30\%), planted eucalyptus forest (59\%) and forest roads $(11 \%)$. The $\mathrm{C}$ factor map was generated using results obtained by Martins et al. (2010b). From such study, the $\mathrm{C}$ factor values were 0.297 and 0.017 for the eucalyptus plantation and the Atlantic Forest (native ecosystem), respectively.

\section{Spatial Distribution of Soil Loss}

The map of long-term annual average soil loss (Figure 6) was created using Equation (1) and this calculation was done multiplying the USLE factors by means of a GIS. The soil loss values calculated ranged from $2 \times 10^{-3}$ to $983 \mathrm{Mg} \mathrm{ha}^{-1} \mathrm{yr}^{-1}$, with a weighted average value equal to $6.2 \mathrm{Mg} \mathrm{ha}^{-1} \mathrm{yr}^{-1}$. The annual soil loss values were summarized in Table 1 with adaptation of the classes suggested by Beskow et al. (2009). The qualitative classes for analysis of soil losses were created by authors of this work. In Table 1 we can observe that $68.6 \%$ of the watershed area had an erosion rate under "slight/ moderate" category, with annual soil loss less than $5 \mathrm{Mg}$ $\mathrm{ha}^{-1} \mathrm{yr}^{-1}$. This can be explained due to the predominance of low slope gradient (Figure 4) and the soil mineralogy in the watershed, in which soils have a high kaolinite content with very low gibbsite and iron-oxide (DUARTE et al., 2000), favoring blocky structure and increasing cohesion and, consequently, decreasing soil erosion. In addition, the greatest part of the watershed $(65 \%)$ has LS factor less than 1.0 (Figure 5) and an adequate cover management (MARTINS et al., 2010b). We can conclude that such factors contributed to the very low erosion rate, although the rainfall erosivity factor was considered high according to Foster et al. (1981).

The results indicated that from "high" to "extremely high" erosion risk occurs in $8.7 \%$ of the area (Table 1 ). The greatest soil erosion values were found in sites occupied by forest roads and with high LS values. This kind of information is extremely valuable since it can be used to plan the soil and water management in a watershed focusing on sites with high potential for water erosion. Sediment delivery control practices, such as sediment basins, barriers, containment structures, and vegetable drainage ditches, should be constructed in order to minimize the movement of sediments, thus reducing the process of sediment transport. The construction of forest roads removes natural protection and makes soil movement easier, thus making these roads more vulnerable to the effect of rainfall erosivity. 


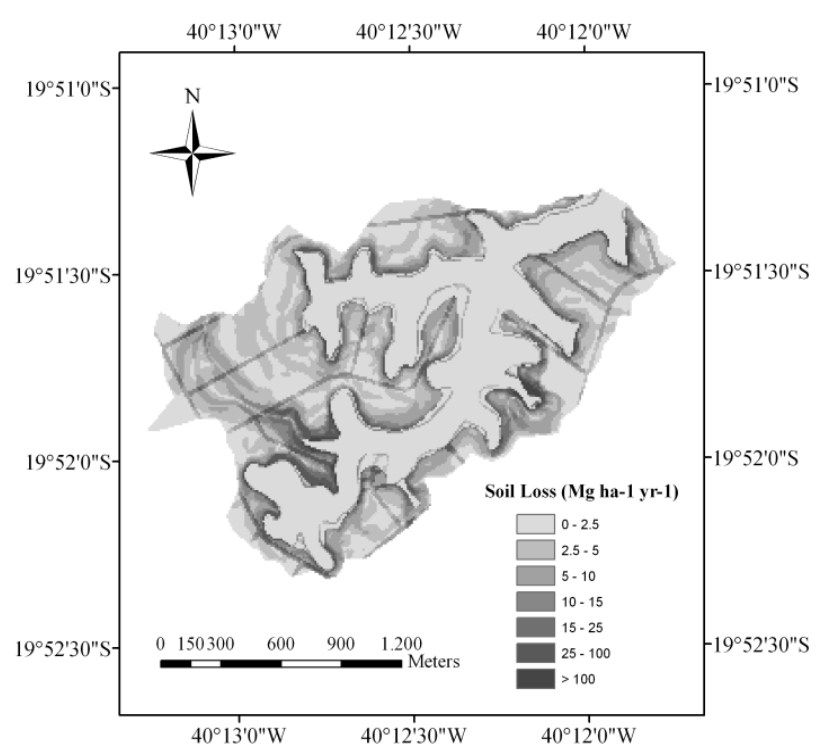

Figure 6 - Map of soil loss for the studied area.

Table 1 - Classes of soil loss for the studied watershed, adapted from Beskow et al. (2009), and soil loss class qualitatively.

\begin{tabular}{ccc}
\hline $\begin{array}{c}\text { Soil loss rate } \\
\mathrm{Mg} \mathrm{ha}^{-1} \mathrm{yr}^{-1}\end{array}$ & $\begin{array}{c}\text { Area } \\
\%\end{array}$ & Qualitative soil loss class \\
\hline $0.0-2.5$ & 49.0 & Slight \\
$2.5-5$ & 19.6 & Slight/Moderate \\
$5-10$ & 16.3 & Moderate \\
$10-15$ & 6.4 & Moderate/High \\
$15-25$ & 4.2 & High \\
$25-100$ & 3.7 & Very High \\
$>100$ & 0.8 & Extremely High \\
\hline
\end{tabular}

The FX soil (Figure 1), primarily that portion located on the western of the watershed, presented the greatest soil loss (Figure 6). During the field work, we observed that lateral water flow occurred intensively in this soil, having this fact a direct relation with a greater loss of silt and clay in suspension, therefore, erosion control practices should be concentrated for protecting these soils.

Comparing the soil loss estimates for different land uses in the watershed (Table 2), it was possible to verify that the natural system - Atlantic Forest, had lower values of mean and median than the other land uses. Additionally, a substantial difference for soil loss was found between Atlantic Forest and forest roads. The eucalyptus land use presented soil loss values for mean and median lesser than tolerable values for soil loss, in the order of 10, 11 and 5 $\mathrm{Mg} \mathrm{ha}^{-1} \mathrm{yr}^{-1}$ for the PA1, FX and PA2, respectively (MARTINS et al., 2010b). However, these soil losses were greater than those for Atlantic Forest. Better management practices should be considered for the eucalyptus area such that erosion rate can be brought much closer to the native forest with objective of making it more sustainable.

Table 2 - Soil loss for different uses for the studied watershed.

\begin{tabular}{lcc}
\hline \multicolumn{1}{c}{ Soil use } & \multicolumn{2}{c}{ Soil loss $\left(\mathrm{Mg} \mathrm{ha}^{-1} \mathrm{yr}^{-1}\right)$} \\
Mean & Median \\
\hline Atlantic Forest & 0.94 & 0.19 \\
Eucalyptus & 6.97 & 3.53 \\
Forest roads & 21.79 & 7.13 \\
\hline
\end{tabular}

Most of the area in the studied watershed (83\%) had a soil loss rate less than soil loss tolerance (Figure 7). However, 48.6 hectares (17\%) of the watershed area, where erosion was greater than soil loss tolerance, needs special attention for the implementation of soil erosion controls.

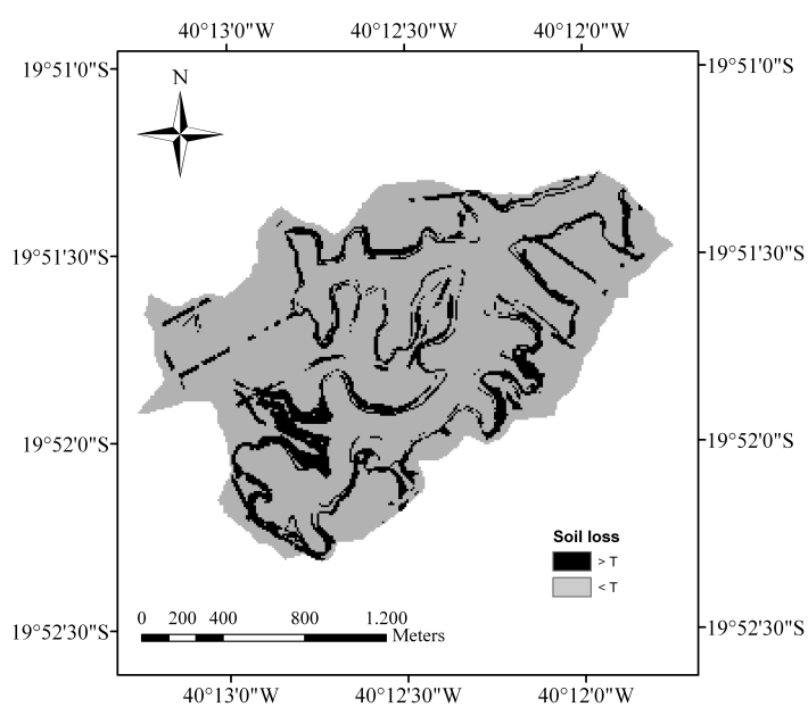

Figure 7 - Spatial distribution map of soil loss greater and lesser than tolerable rate for the studied watershed.

\section{CONCLUSIONS}

In terms of soil loss classes, $49 \%$ of the area is classified as slight soil loss, with values smaller than 
$2.5 \mathrm{Mg} \mathrm{ha}^{-1} \mathrm{yr}^{-1}$. However, about $8.7 \%$ of the watershed area had soil erosion greater than $15 \mathrm{Mg} \mathrm{ha}^{-1} \mathrm{yr}^{-1}$, being classified as high soil loss or upper, where conservation practices need to be implemented to control soil erosion.

The long-term average annual soil loss for the studied watershed was $6.2 \mathrm{Mg} \mathrm{ha}^{-1} \mathrm{yr}^{-1}$. About $86 \%$ of the watershed area presented soil erosion rate less than the tolerable value, indicating generally adequate management for such areas. Although the long-term average annual soil loss for eucalyptus was less than the tolerable value, conservation practices should be employed in order to decrease erosion rate much closer to the Atlantic Forest to reduce offsite effects and degradation. In addition, erosion control practices should be concentrated on the FX soils and roads.

The implementation of the USLE model in a GIS environment was found to be a simple and useful tool for predicting the spatial distribution of soil erosion risk and identifying critical areas for the studied watershed in the Coastal Plain of Espírito Santo state, Brazil.

\section{ACKNOWLEDGEMENTS}

We thank the Research Foundation of the State of Minas Gerais - FAPEMIG, the Brazilian National Council for Scientific and Technological Development - CNPq, the Brazilian Coordination for the Improvement of Higher Education Personnel - CAPES and the Fibria Celulose S.A.

\section{REFERENCES}

BESKOW, S. et al. Soil erosion prediction in the Grande River Basin, Brazil using distributed modeling. Catena, Amsterdam, v.79, n.1, p.49-59, Oct. 2009.

BHATTARAI, R.; DUTTA, D. Estimation of soil erosion and sediment yield using GIS at catchment scale. Water Resources Management, Amsterdam, v.21, n.10, p.16351647, Oct. 2007.

DABRAL, P.P.; BAITHURI, N.; PANDEY, A. Soil erosion assessment in a hilly catchment of North Eastern India using USLE, GIS and remote sensing. Water Resources Management, Amsterdam, v.22, n.12, p.1783-1798, Dec. 2008.

DE ROO, A.P.J.; JETTEN, V.G. Calibrating and validating the LISEM model for two data sets from the Netherlands and South Africa. Catena, Amsterdam, v.37, n.3/4, p.477493, Oct. 1999.
DUARTE, M.N. et al. Mineralogia, química e micromorfologia de solos de uma microbacia nos Tabuleiros Costeiros do Espírito Santo. Pesquisa Agropecuária

Brasileira, Brasília, v.35, n.6, p.1237-1250, Jun. 2000.

\section{EMPRESA BRASILEIRA DE PESQUISAS}

AGROPECUÁRIA- EMBRAPA. Centro Nacional de Pesquisa de Solos. Levantamentos generalizado e semidetalhado de solos da Aracruz Celulose S.A. no Estado do Espírito Santo e no estremo sul do Estado da Bahia e sua aplicação aos plantios de eucalipto. Rio de Janeiro: Embrapa Solos, 2000. parte 3. 111p.

\section{EMPRESA BRASILEIRA DE PESQUISAS}

AGROPECUÁRIA - EMBRAPA. Sistema brasileiro de classificação de solos. 2.ed. Rio de Janeiro: Embrapa Solos, 2006. 306p.

\section{ENVIRONMENTALSYSTEMS RESEARCHINSTITUTE - ESRI. Inc. ArcGIS Professional GIS for the desktop, version 9.3. Software. 2009.}

FOSTER, G.R. et al. Conversion of the universal soil loss equation to SI metric units. Journal of Soil and Water Conservation, Ankeny, v.36, n.6, p.356-359, Nov. 1981.

FOSTER, G.R.; MEYER, L.D.; ONSTAD, C.A. Arunoff erosivity factor and variable slope length exponents for soil loss estimates. Transactions of the American Society of Agricultural Engineers, Saint Joseph, v.20, n.1, p.683-687, Jan. 1977.

LE COMTE, D. The global spin: international weather highlights for 2004. Weatherwise, London, v.58, n.2, p.23-29, 2005.

MARTIN, D.; SAHA, S.K. Integrated approach of using remote sensing and GIS to study watershed prioritization and productivity. Journal of the Indian Society of Remote Sensing, Dehradun, v.35, n.1, p.2130, Mar. 2007.

MARTINS S.G. et al. Rainfall erosivity and rainfall return period in the experimental watershed of Aracruz, in the coastal plain of Espírito Santo, Brazil. Revista Brasileira de Ciência do Solo, Viçosa, v.34, n.3, p.999-1004, 2010a.

MARTINS, S.G. et al. Erodibilidade do solo nos Tabuleiros Costeiros. Pesquisa Agropecuária Tropical, Goiânia, v.41, n.3, p.322-327, 2011. 
MARTINS, S.G. et al. Fator cobertura e manejo do solo e perdas de solo e água em cultivo de eucalipto e em Mata Atlântica nos Tabuleiros Costeiros do estado do Espírito Santo. Scientia Forestalis, Piracicaba, v.38, n.87, p.517$526,2010 \mathrm{~b}$.

McCOOL, D.K. et al. Revised slope steepness factor for the Universal Soil Loss Equation.

Transactions of the American Society of Agricultural Engineers, Saint Joseph, v.30, n.5, p.1387-1396, Sept./Oct. 1987.

McCOOL, D.K. et al. Revised slope length factor for the Universal Soil Loss Equation. Transactions of the American Society of Agricultural Engineers, Saint Joseph, v.32, n.5, p.1571-1576, Sept./Oct. 1989.

McTAGGART-COWAN, R. et al. Analysis of Hurricane Catarina (2004). Monthly Weather Review, Washington, v.134, n.11, p.3029-3053, Nov. 2006.

PANDEY, A.; CHOWDARY, V.M.; MAL, B.C.

Identification of critical erosion prone areas in the small agricultural watershed using USLE, GIS and remote sensing. Water Resources Management, Amsterdam, v.21, n.4, p.729-746, Apr. 2007.

RENARD, K.G. et al. Predicting soil erosion by water: a guide to conservation planning with the Revised Universal Soil Loss Equation (RUSLE). Washington: U.S. Department of Agriculture, 1997. 404p. (Agriculture Handbook, 703).

TUCCI, C.E.M. Modelos hidrológicos. Porto Alegre: ABRH/UFRGS, 1998. 669p.

WISCHMEIER, W.H.; SMITH, D.D. Predicting rainfall erosion losses: a guide to conservation planning. Washington: USDA, 1978. 58p. (Agriculture Hand-book, 537)

YUKSEL, A.; GUNDOGAN, R.; AKAY, A.E. Using the remote sensing and GIS technology for erosion risk mapping of Kartalkaya Dam Watershed in Kahramanmaras, Turkey. Sensors, Peterborough, v.8, n.8, p.4851-4865, Aug. 2008. 